\title{
Clinical outcomes with high-dose-rate surface mould brachytherapy for intra-oral and skin malignancies involving head and neck region
}

\author{
Ashwini Budrukkar, MD!, Archya Dasgupta, MD!, Prakash Pandit, MD!, Sarbani Ghosh Laskar, MD!, Vedang Murthy, MD! \\ Ritu Raj Upreti, MSc², Tejpal Gupta, MD!, Kanchan Dholam, MDS³, Jai Prakash Agarwal, MD' \\ 'Department of Radiation Oncology, ${ }^{2}$ Department of Medical Physics, ${ }^{3}$ Department of Dental Services, Tata Memorial Hospital, Parel, \\ Mumbai, India
}

\begin{abstract}
Purpose: The literature and experience of high-dose-rate (HDR) surface mould brachytherapy (SMB) in head and neck cancer is sparse. We report our institutional experience of SMB for such tumours.

Material and methods: Thirty-five patients with malignant localized early T1/T2, N0 (21 intra-oral and 14 skin) tumours treated with SMB during 2008-2014 were analyzed. Treatment was delivered using HDR ${ }^{192} \mathrm{Ir}$ source to a median dose of 49 Gy (range, 38.5-52.5 Gy) as radical brachytherapy and 18 Gy (range, 15.5-30 Gy) as boost with 3-4 Gy/ fraction twice daily using customized surface mould.

Results: Median follow-up was 52 months (range, 6 to 98 months). Local control (LC) for skin tumours and intra-oral malignancies at 5 years were $92 \%$ and $76 \%$, respectively. Five-year cause specific survival was $92 \%$. For T1 and T2 tumours, 5 year LC was $94.2 \%$ and $68.2 \%$, respectively. T stage $(p<0.04)$ and dose/fractions $(p<0.003)$ were the only significant prognostic factors for LC on univariate analysis.

Conclusions: Surface mould brachytherapy results in excellent LC rates for skin tumours and T1 intraoral tumours when considered as radical treatment, and preferable to consider it as a boost for T2 intraoral tumours. Surface mould brachytherapy results in excellent organ and function preservation.

J Contemp Brachytherapy 2017; 9, 3: 242-250 DOI: https://doi.org/10.5114/jcb.2017.66773
\end{abstract}

Key words: brachytherapy, head and neck, skin, surface mould.

\section{Purpose}

Surface mould brachytherapy (SMB) is a well-established treatment for early stage head and neck cancers involving accessible sites. It has evolved from the radium era to low-dose-rate (LDR) and now to high-dose-rate (HDR) intensity modulated interventional brachytherapy [1]. The use of brachytherapy (BT), both in radical setting and as salvage procedure, have resulted in satisfactory outcomes for head and neck malignancies [2,3]. Surface mould brachytherapy has shown excellent outcomes using LDR brachytherapy [4]. High-dose-rate brachytherapy is now widely used in many parts of the world and has shown to have equivalent outcomes compared to other dose rates for some head and neck malignancies [5]. There have been few reports regarding the use of SMB in the HDR era for skin malignancies involving skin of face (including nose, pinna) resulting in outcomes comparable with other treatment strategies $[6,7,8,9]$. However, very limited literature is available for SMB for intra-oral malignancies and involved less number of patients $[10,11,12]$. This analysis was undertaken to find out the clinical outcomes of superficial tumours of head and neck region treated with SMB, in terms of survival and toxicity.

\section{Material and methods}

Between January 2008 and December 2014, 35 patients were treated with HDR brachytherapy using surface mould. Data was retrieved from prospectively maintained database and patient charts.

\section{Patient selection}

Superficial tumours of head and neck region (T1-T2N0 M0) over accessible sites like hard palate, hard-soft palate junction or over the skin like cheek, nose, and ear were considered for treatment with SMB. The decision of treating with SMB was undertaken after reviewing the disease site, and discussing with the medical physicist and mould room technician regarding feasibility of the procedure and possibility of adequate target volume coverage. For patients
Address for correspondence: Prof. Ashwini Budrukkar, MD, Department of Radiation Oncology, Tata Memorial Hospital, Ernest Borges Marg, Parel, Mumbai, India 400012, phone: +91 22 24177152, fax: +91 22 24146747, ఐ e-mail: ashwininb@yahoo.com
Received: 11.11.2016 Accepted: 08.02.2017 Published: 30.06 .2017 
with primary over hard palate or soft palate, additional consultation with the dental department was done regarding preparation of the dental carrier material.

\section{Procedure}

The workflow of procedure for SMB is shown in Figure 1. Customized mould was made for each patient. Gross tumour with $1 \mathrm{~cm}$ margin was considered as the clinical target volume and was marked on the patient. First component of SMB included preparation of the carrier material. The area, over which the cast was to be prepared, was marked over the skin. For tumours located over skin, a negative impression was made using dental alginate material (Alginate Dental Impression Material, The Bombay Burmah Trading Corporation Ltd.) (Figure 2A). Stone cast or plaster of Paris cast was used to remove the alginate. The negative impression was obtained by removing the assembly after 15 to 20 minutes. The positive cast using stone cast (kalstone) powder was made by filling the hollow of the alginate cast, which was then kept for 10-15 hours. The carrier material ( $2 \mathrm{~mm}$ thick) was made by use of self-curing dental acrylic material to cover the target area and a part of the body con- tour surrounding it. As per necessities, velcro straps were attached to the carrier for comfortable fitting during treatment (Figure 2B). For intra-oral tumours, the carrier prosthesis was made using similar procedure of negative and positive cast making in the dental department (Figure 2C). A dental obturator was made over the positive cast, which was used as a carrier material.

Wax sheets were applied over the carrier material for reinforcement of the catheters to obtain a distance of $5 \mathrm{~mm}$ from the surface. Nylon catheters were placed over the wax at a spacing of $10 \mathrm{~mm}$ to ensure coverage of the target volume. After the catheters were fixed to the carrier, the entire assembly was tested over the patient for proper fitting (Figure 2B, 2D).

\section{Brachytherapy planning and treatment}

Three dimensional computed tomography (CT) based planning was done using thin CT slices of 1 to $1.25 \mathrm{~mm}$ slice thickness on Somatom Emotion (Siemens Medical Systems, Germany). To ensure proper visualization, metallic markers or thin copper wires were placed at the edges of the tumour and in the tubes. On the planning scan, the proper fitting of

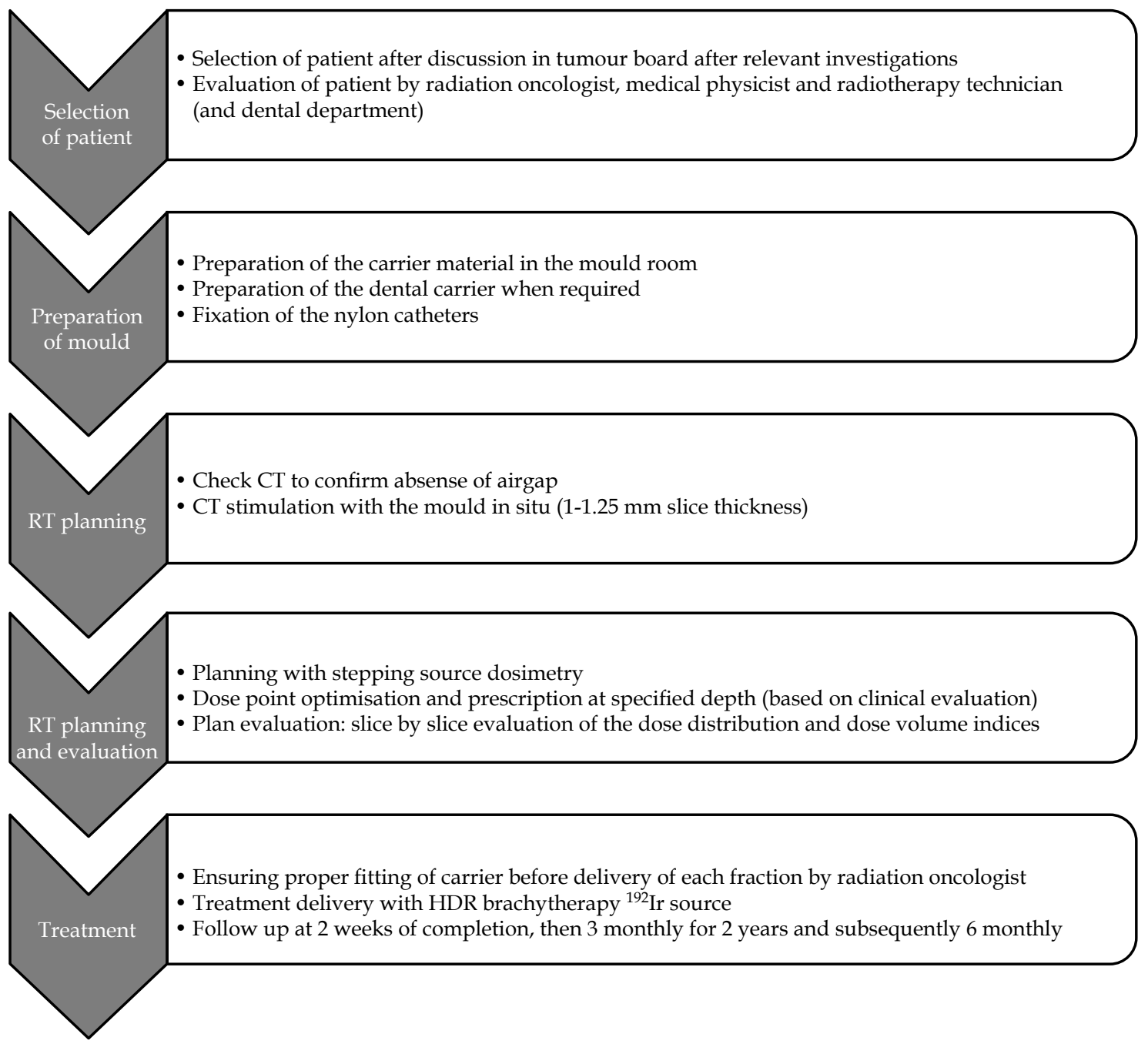

Fig. 1. Workflow of the procedure of surface mould brachytherapy 

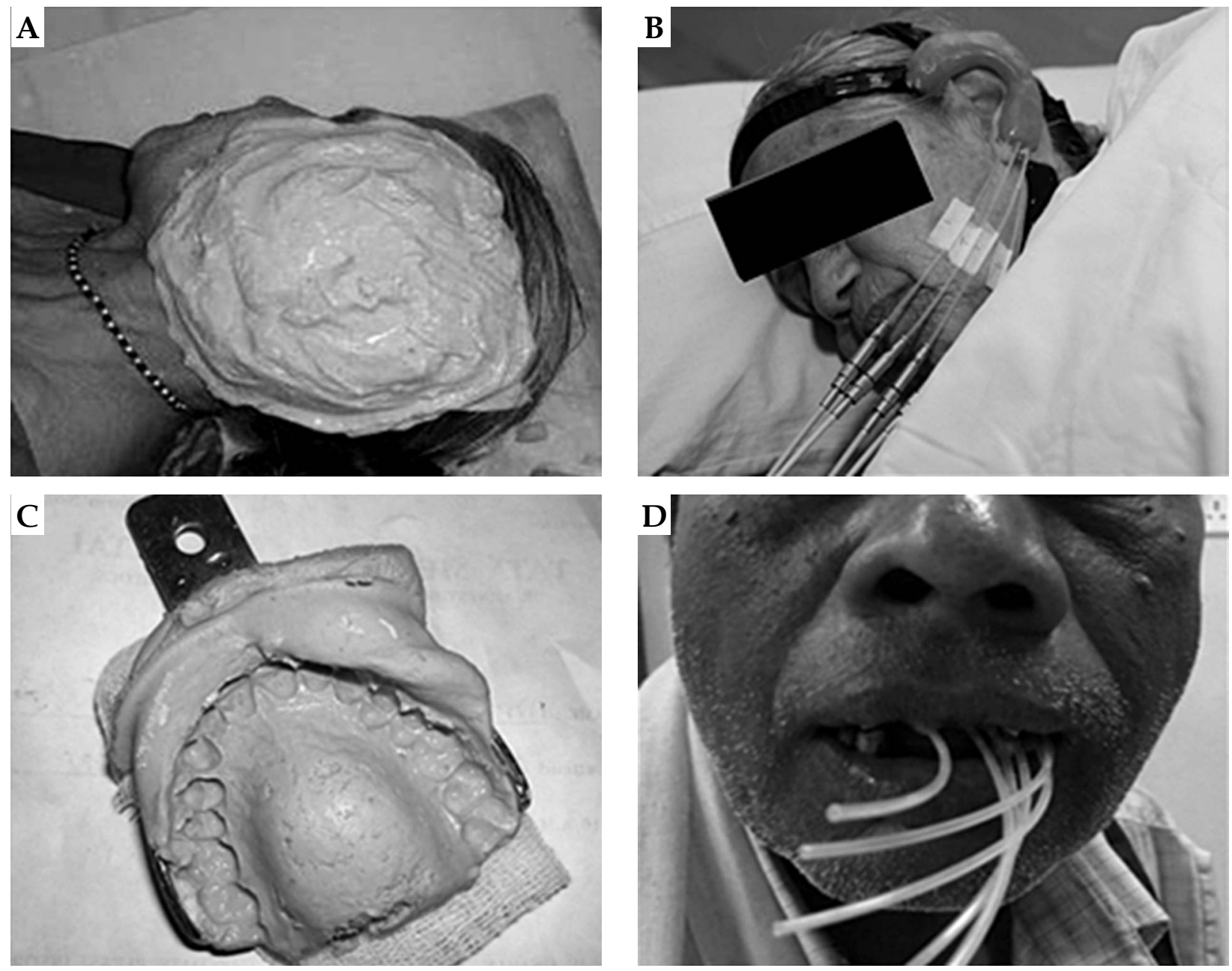

Fig. 2. Preparation of carrier material and assembly during treatment in patients treated with surface mould brachytherapy for head and neck cancers. A) Application of alginate material over pinna and surrounding region for preparation of the carrier for a patient with basal cell carcinoma of pinna. B) The mould with catheters in situ connected to the treatment machine. C) Dental impression prepared for a patient with squamous carcinoma of hard palate. D) The mould assembly in position for the same patient just prior to treatment delivery

the mould material was verified, and in case of improper fitting with intervening air gaps, repeat images were undertaken or the entire procedure was repeated on some occasions. Planning was done using Oncentra brachytherapy version 3.3 and 4.1 (Nucletron, an Elekta company, Elekta $\mathrm{AB}$, Stockholm, Sweden). Catheter reconstruction was done using multiplanar reconstruction, and loading was decided based on the target volume marked on patient. Dose points were defined at 5-7 $\mathrm{mm}$ from the source and dose distribution was obtained. Dose point optimization was done for all the patients. Evaluation of the plan was done with slice-by-slice visualization of the target coverage. Dose was prescribed at $100 \%$ isodose line in 33 patients and at $85 \%$ in 2 patients. Parameters such as $\mathrm{V}_{100}, \mathrm{~V}_{150}, \mathrm{~V}_{200}$, and dose homogeneity index (DHI) were evaluated for each patient. In $\mathrm{SMB}$, majority of $\mathrm{V}_{150}$ and $\mathrm{V}_{200}$ were observed inside the carrier prosthesis, and hence had little impact on the plan evaluation process. Dose per fraction of 3-4 Gy, twice daily, 6 hours apart was considered. Total dose ranged from 38.5 Gy to $52.5 \mathrm{~Gy}$ in 11-15 fractions in radical setting, and 15-30 Gy in 5-10 fractions as boost.
Radical brachytherapy was considered for tumours of skin and T1 tumours of intraoral region. The aim was to deliver doses of 54-60 Gy equivalent dose of $2 \mathrm{~Gy}\left(\mathrm{EQD}_{2}\right)$ (Table 1). Combined external beam radiotherapy (EBRT) and SMB boost was considered in intraoral tumours with T2 lesions. The external beam radiotherapy was considered prior to SMB to a dose ranging from 44 to $60 \mathrm{~Gy}$ (median, $50 \mathrm{~Gy}$ ) at $2 \mathrm{~Gy}$ per fraction. In these patients, the aim was to achieve total combined dose of 66-72 Gy $\mathrm{EQD}_{2}$ (Table 1). The appropriate fitting of the mould was verified and presence of airgap checked clinically before each fraction by the treating radiation oncologist.

On completion of the treatment, in case of skin reactions, patients were prescribed topical steroid creams. The radiation related toxicities were classified according to the Radiation Therapy Oncology Group (RTOG) grading system. The first review was done at 2 weeks from completion, then at 6 weeks, and subsequently every 3 months, till 2 years and then 6 monthly. On follow-up, detailed clinical examination was undertaken and further investigations were done only if warranted clinically. Pre-radiotherapy 
Table 1. Patient and treatment details of 35 patients treated with surface mould brachytherapy (SMB) for head and neck cancers

\begin{tabular}{|c|c|c|}
\hline Factor & Number, frequency & (\%) \\
\hline \multicolumn{3}{|l|}{ Age } \\
\hline Median & \multicolumn{2}{|c|}{53 years (range, $25-85$ years } \\
\hline \multicolumn{3}{|l|}{ Sex } \\
\hline Male & 26 & 74 \\
\hline Female & 9 & 26 \\
\hline \multicolumn{3}{|l|}{ Histology } \\
\hline Squamous & 29 & 83 \\
\hline Basal cell carcinoma & 6 & 17 \\
\hline \multicolumn{3}{|l|}{ Site } \\
\hline Hard palate & 15 & 43 \\
\hline Soft palate & 3 & 9 \\
\hline HP-SP junction & 2 & 6 \\
\hline Tonsil & 1 & 3 \\
\hline Nose & 9 & 25 \\
\hline Skin face & 4 & 11 \\
\hline Pinna & 1 & 3 \\
\hline \multicolumn{3}{|l|}{ Tumour size } \\
\hline Median & \multicolumn{2}{|c|}{$2 \mathrm{~cm}$ (range, $0.7-4.0 \mathrm{~cm}$ ) } \\
\hline \multicolumn{3}{|l|}{ Treatment } \\
\hline Radical & 27 & 77 \\
\hline Boost & 8 & 23 \\
\hline \multicolumn{3}{|l|}{ Dose EBRT } \\
\hline Median & \multicolumn{2}{|c|}{50 Gy (range, 44-60 Gy) } \\
\hline \multicolumn{3}{|l|}{ Dose SMB (radical) } \\
\hline Median & 49 Gy (range, 38 & Gy) \\
\hline
\end{tabular}

\begin{tabular}{|c|c|}
\hline Factor & Number, frequency \\
\hline \multicolumn{2}{|l|}{ Dose SMB (as boost) } \\
\hline Median & 18 Gy (range, 15.5-30 Gy) \\
\hline \multicolumn{2}{|l|}{ Catheters } \\
\hline Median & 5 (range, 3-7) \\
\hline \multicolumn{2}{|l|}{$\mathrm{V}_{85}$} \\
\hline Median & $35.76 \mathrm{cc}$ (range, 17.89-72.22 cc) \\
\hline \multicolumn{2}{|l|}{$\mathrm{V}_{90}$} \\
\hline Median & 33.32 cc (range, 12.08-61.25 cc) \\
\hline \multicolumn{2}{|l|}{$V_{100}$} \\
\hline Median & 25.6 cc (range, 9.9-46.3 cc) \\
\hline \multicolumn{2}{|l|}{$V_{150}$} \\
\hline Median & 12.6 cc (range, 3.8-22.9 cc) \\
\hline \multicolumn{2}{|l|}{$\mathrm{DHI}$} \\
\hline Median & 0.509 (range, 0.44-0.69) \\
\hline \multicolumn{2}{|c|}{ Overdose volume index (ODI) } \\
\hline Median & 0.24 (range, 0.14-0.36) \\
\hline \multicolumn{2}{|c|}{ Dose non-uniformity ratio (DNR) } \\
\hline Median & 0.49 (range, 0.31-0.56) \\
\hline \multicolumn{2}{|l|}{$\mathrm{EQD}_{2}$ of radical $\mathrm{SMB}$} \\
\hline Median & 55 Gy (range, 43.3-59.06 Gy) \\
\hline \multicolumn{2}{|l|}{$\mathrm{EQD}_{2}$ of boost $\mathrm{SMB}$} \\
\hline SMB dose, median & 19.5 Gy (16.25-28.4 Gy) \\
\hline Total dose, median & 71.8 Gy (63.5-88.4 Gy) \\
\hline
\end{tabular}

HP-SP - hard palate-soft palate, $V_{85}$-volume receiving $85 \%$ of prescribed dose, $V_{90}$-volume receiving $90 \%$ of the prescribed dose, $V_{100}-$ volume receiving $100 \%$ of prescribed dose, $V_{150}$-volume receiving $150 \%$ of prescribed dose, $D H I-$ dose homogeneity index $=V_{100}-V_{150} V_{100}$, ODI - overdose volume index $=V_{200} V_{100}$, DNR - dose non-uniformity ratio: $V_{150} V_{100}, E Q D_{2}$-dose equivalent to 2 Gy per fraction

and post-radiotherapy visual evaluation of cosmetic outcome was done in all patients. The outcomes were subjectively scored as excellent, good, fair, or poor by the treating radiation oncologist. For assessment of function preservation for skin or hard palate tumours, integrity of the organ without any complication was taken as desired end point.

\section{Statistics}

Statistical analysis was done using Statistical Package for the Social Sciences (SPSS V21) software. Kaplan Meier methods were used for analysis of survival outcomes and curves were plotted accordingly. The date of starting radiotherapy was taken for calculation of the survival, and date of recurrence was the date of clinically or radiologi- cally relapsed disease. The prognostic factors for survival were compared using log-rank test (Mantel-Cox) for univariate analysis, and Cox regression for multivariate analysis. A $p$-value of less than 0.05 was considered to be of statistical significance. $X^{2}$ test was performed for assessment of toxicity and relation with various factors.

\section{Results}

\section{Patient and treatment characteristics}

The patient characteristics and treatment details are summarized in Table 1 . The median time from onset of symptoms to diagnosis was 5 months (range, 1-36 months). In 31 patients, SMB was used as the primary 


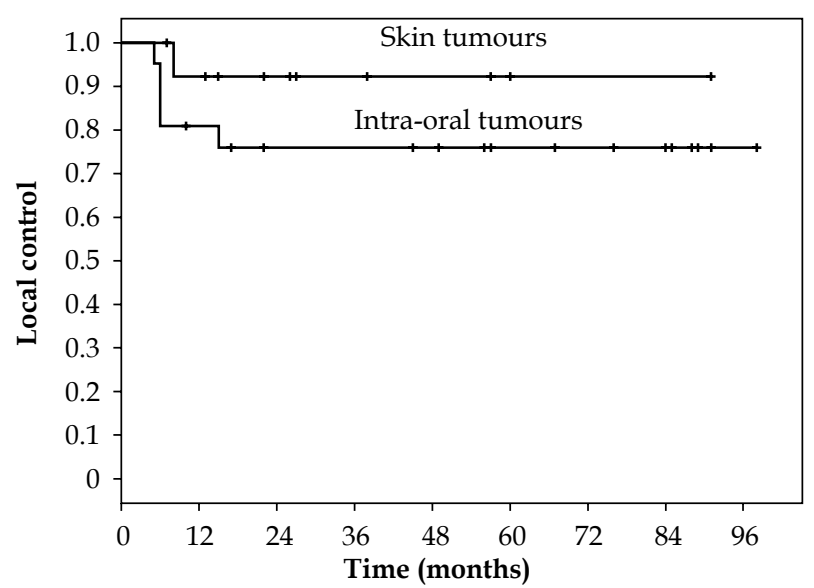

Fig. 3. Kaplan Meier plot showing local control in patients treated with surface mould brachytherapy for head and neck cancers

treatment modality, and in four patients, for disease recurrence as the second primary. The growth was ulcerative in 13 patients, ulceroproliferative in 12 , proliferative in 6, infiltrative and superficial creeping in 2 patients each.

In 8 patients, SMB was used as boost after EBRT. Of these, 7 patients had lesions in palate ( 3 soft palate, 2 hard palate, and 2 over the soft palate/hard palate junction), and 1 over tonsil. Seven patients were treated using parallel opposed portals, while in 1 patient IMRT (soft palate primary) was considered. Median gap between
EBRT and BT was 14 days (range, 8 to 28 days). Concurrent weekly chemotherapy with cisplatinum $\left(30 \mathrm{mg} / \mathrm{m}^{2}\right)$ was used during EBRT in 2 patients with carcinoma soft palate due to bulky disease. For patients treated with brachytherapy alone, the treatment duration ranged from 5 to 11 days (median, 7 days). Dosimetric data was available for 30 patients and has been summarized in Table 1 .

\section{Outcomes}

\section{Local control}

The median follow-up for surviving patients was 52 months (range, 6 to 98 months). Two and 5-year local control (LC) was $82 \%$ for the entire cohort. There were 6 local failures ( 1 nose, 3 hard palate, 1 hard-soft palate junction, 1 tonsil). The median time to recurrence was 6 months (range, 5 to 15 months). For skin and intra-oral malignancies, 5-year LC rates were $92 \%$ and $76 \%$, respectively (Figure 3). The 5-year LC rate for basal cell carcinoma was $100 \%$, while for squamous carcinoma it was $79 \%$. Patients treated in upfront setting had 5-year LC of $86 \%$ while it was $50 \%$ for recurrent disease. Patients with hard palate lesions had 5-year LC of 79\%.

\section{Patterns of failure}

In addition to the 5 local recurrences, 1 patient had combined primary and nodal failure. Two patients (both hard palate) had isolated nodal failures (involv-

Table 2. Patterns of failure in 35 patients treated with surface mould brachytherapy for head and neck cancers

\begin{tabular}{|c|c|c|c|c|c|}
\hline Site & Recurrence (months) & $\begin{array}{c}\text { Treatment } \\
\text { of recurrence }\end{array}$ & Response & $\begin{array}{l}\text { Last follow-up } \\
\text { (months) }\end{array}$ & $\begin{array}{c}\text { Status during last } \\
\text { follow-up }\end{array}$ \\
\hline \multicolumn{6}{|c|}{ Isolated primary failure } \\
\hline Hard palate & 5 & MCT & Progression & 16 & $\begin{array}{l}\text { Death due to } \\
\text { disease }\end{array}$ \\
\hline HP-SP junction & 6 & MCT & Progression & 20 & $\begin{array}{l}\text { Death due to } \\
\text { disease }\end{array}$ \\
\hline Tonsil (rec) & 6 & $\begin{array}{l}\text { Surgery with } B / L \\
\text { MND }\end{array}$ & $C R$ & 8 & Alive NED \\
\hline Nose & 8 & Surgery & $C R$ & 47 & $\begin{array}{l}\text { Died of cardiac } \\
\text { cause }\end{array}$ \\
\hline Hard palate & 15 & Wide local excision & $C R$ & 59 & Alive NED \\
\hline \multicolumn{6}{|c|}{ Primary and nodal failure } \\
\hline Hard palate (rec) & 5 & Planned for surgery & $\begin{array}{l}\text { Treatment } \\
\text { pending }\end{array}$ & 6 & Alive with disease \\
\hline \multicolumn{6}{|l|}{ Isolated nodal failure } \\
\hline Hard palate & 7 & $\mathrm{~B} / \mathrm{L} M N D$ & $C R$ & 49 & Alive NED \\
\hline Hard palate & 18 & $\begin{array}{c}\text { I/L MND f/b adj } \\
\text { EBRT }\end{array}$ & $C R$ & 67 & Alive NED \\
\hline \multicolumn{6}{|c|}{ Third primary (both were treated for second primary) } \\
\hline Hard palate (rec) & $\begin{array}{c}4 \text { ( } 3^{\text {rd }} \text { primary in tonsil } \\
\text { with suprasternal nodes) }\end{array}$ & MCT & Progression & 17 & $\begin{array}{l}\text { Died of progression } \\
\text { from } 3^{\text {rd }} \text { primary }\end{array}$ \\
\hline Hard palate (rec) & $\begin{array}{c}20 \text { (small primary in lateral } \\
\text { tongue) }\end{array}$ & WLE & $C R$ & 91 & Alive NED \\
\hline
\end{tabular}

MCT - metronomic chemotherapy, B/L - bilateral, MND - modified neck dissection, $C R$ - complete response, NED - no evidence of disease, I/L - ipsilateral, EBRT - external beam radiation therapy, WLE - wide local excision, last follow-up measured from baseline date 
ing ipsilateral level IB and II). Two patients who were treated for second primary, developed third primary cancer subsequently (1 soft palate and hard palate each) (Table 2).

\section{Survival}

For the entire cohort, 2 and 5-year disease free survival (DFS) was $69 \%$. Of the 5 local recurrences, 3 patients underwent successful salvage surgery and 2 were considered for palliative metronomic chemotherapy (in view of extensive local disease). One patient with primary and nodal disease was being considered for surgical salvage at the last follow-up. Two patients with nodal recurrence underwent salvage neck dissection. Of the 2 patients with $3^{\text {rd }}$ primary tumour, 1 underwent successful salvage surgery, while another patient was considered for metronomic chemotherapy. The 2-year and 5-year cause specific survival (CSS) was $92 \%$.

Of all the patients with recurrent disease, 3 patients on palliative metronomic chemotherapy died due to disease. Two other unrelated deaths were seen ( 1 each from cardiac cause and pyrexia of likely infective etiology), both controlled of disease. The 2 and 5-year, overall survival (OS) was $86 \%$ and $81 \%$, respectively.

\section{Prognostic factors}

Various prognostic factors for LC are summarized in Table 3. T stage (T1 vs. T2) and dose per fraction (3 Gy or more) were the only significant factors. Local control for $\mathrm{T} 1$ and $\mathrm{T} 2$ tumours were $94.2 \%$ and $68.2 \%$, respectively $(p=0.04)$. Patients treated with $>3$ Gy had 5-year LC of $92 \%$ when compared to $50 \%$ for those treated with $3 \mathrm{~Gy} /$ fraction $(p=0.003)$. Although statistically insignificant, better control rates were seen for tumours treated in upfront setting, basal cell histology and tumours located over skin. On multivariate analysis, none of the prognostic factors were found to be significant. Also, none of the factors were seen to impact DFS, CSS, or OS significantly.

\section{Toxicity}

Grade 1 late subcutaneous fibrosis was seen in $17 \%$. Three patients developed hypopigmentation (all for nose primary). Telangiectasia was seen in 9 patients. Grade 1 xerostomia was seen in 6 patients, all of them had received EBRT. One patient developed palatal perforation of the soft palate, and in 1 patient bone was exposed. None of the factors (patient, tumour, or treatment related) were significantly associated with toxicity on univariate or multivariate analysis. Surface mould brachytherapy resulted in organ and function preservation in all patients (Figure 4A, 4B). The late cosmesis was excellent in patients with skin tumours (Figure 4C, 4D).

\section{Discussion}

Surface mould brachytherapy is a well-established treatment for the surface tumours of head and neck region, and used since many decades. However, there are only few reports of outcome with SMB using HDR brachyther-
Table 3. Prognostic factors affecting local control in 35 patients treated with surface mould brachytherapy for head neck cancers

\begin{tabular}{|c|c|c|c|}
\hline Parameter & $\begin{array}{l}\text { Number } \\
\text { of events } \\
\text { (total } \\
\text { patients) }\end{array}$ & $\begin{array}{l}\text { 5-year local } \\
\text { control (\%) }\end{array}$ & $p$ value \\
\hline \multicolumn{4}{|l|}{ Age } \\
\hline 50 years or less & $2(15)$ & 86.7 & 0.66 \\
\hline More than 50 years & $4(20)$ & 79.1 & \\
\hline \multicolumn{4}{|l|}{ Presentation } \\
\hline Upfront & $4(31)$ & 86.4 & 0.05 \\
\hline Recurrent & $2(4)$ & 50 & \\
\hline \multicolumn{4}{|l|}{ Site } \\
\hline Oral cavity & $5(21)$ & 75.9 & 0.22 \\
\hline Skin & $1(14)$ & 92.3 & \\
\hline
\end{tabular}

\begin{tabular}{lccc}
\hline Histology & & \\
\cline { 1 - 2 } Squamous carcinoma & $6(29)$ & 78.7 & 0.24 \\
\cline { 1 - 2 } Basal cell carcinoma & $0(6)$ & 100 & \\
\cline { 1 - 2 } Tstage & & & \\
\cline { 1 - 2 } T1 & $1(19)$ & 94.2 & 0.04 \\
\hline T2 & $5(16)$ & 68.2 & \\
\hline
\end{tabular}

\begin{tabular}{|c|c|c|c|}
\hline \multicolumn{4}{|l|}{ Treatment } \\
\hline Boost (after EBRT) & $3(8)$ & 62.5 & \multirow[t]{2}{*}{0.05} \\
\hline Radical & $3(27)$ & 88.2 & \\
\hline \multicolumn{4}{|c|}{ Dose (radical setting only) } \\
\hline Less than 49 Gy & $2(13)$ & 84.6 & \multirow[t]{2}{*}{0.46} \\
\hline 49 Gy or more & $1(14)$ & 92.3 & \\
\hline \multicolumn{4}{|l|}{ Dose per fraction } \\
\hline 3 Gy & $4(8)$ & 50.0 & \multirow[t]{2}{*}{0.003} \\
\hline More than 3 Gy & $2(27)$ & 91.9 & \\
\hline
\end{tabular}

EBRT - external beam radiotherapy

apy, and have been summarized in Table 4 . Amongst the published data, majority of the studies have focused on SMB for skin cancers $[6,7,8,9]$. In our study, there were 21 patients with intraoral tumours and 14 patients with skin malignancies. This appears to be one of the largest series of SMB for intraoral malignancies.

We have observed 5-year LC rate of $92 \%$ in patients with skin malignancies. Local recurrence was observed in a single patient with tumour located over the nose. Recurrence was observed 8 months after SMB and was successfully salvaged with surgery. The LC rate in our series is comparable to that of the reported literature. In the series reported by Maronas et al., all the 5 patients who had recurred (of total 48), the tumour was located 

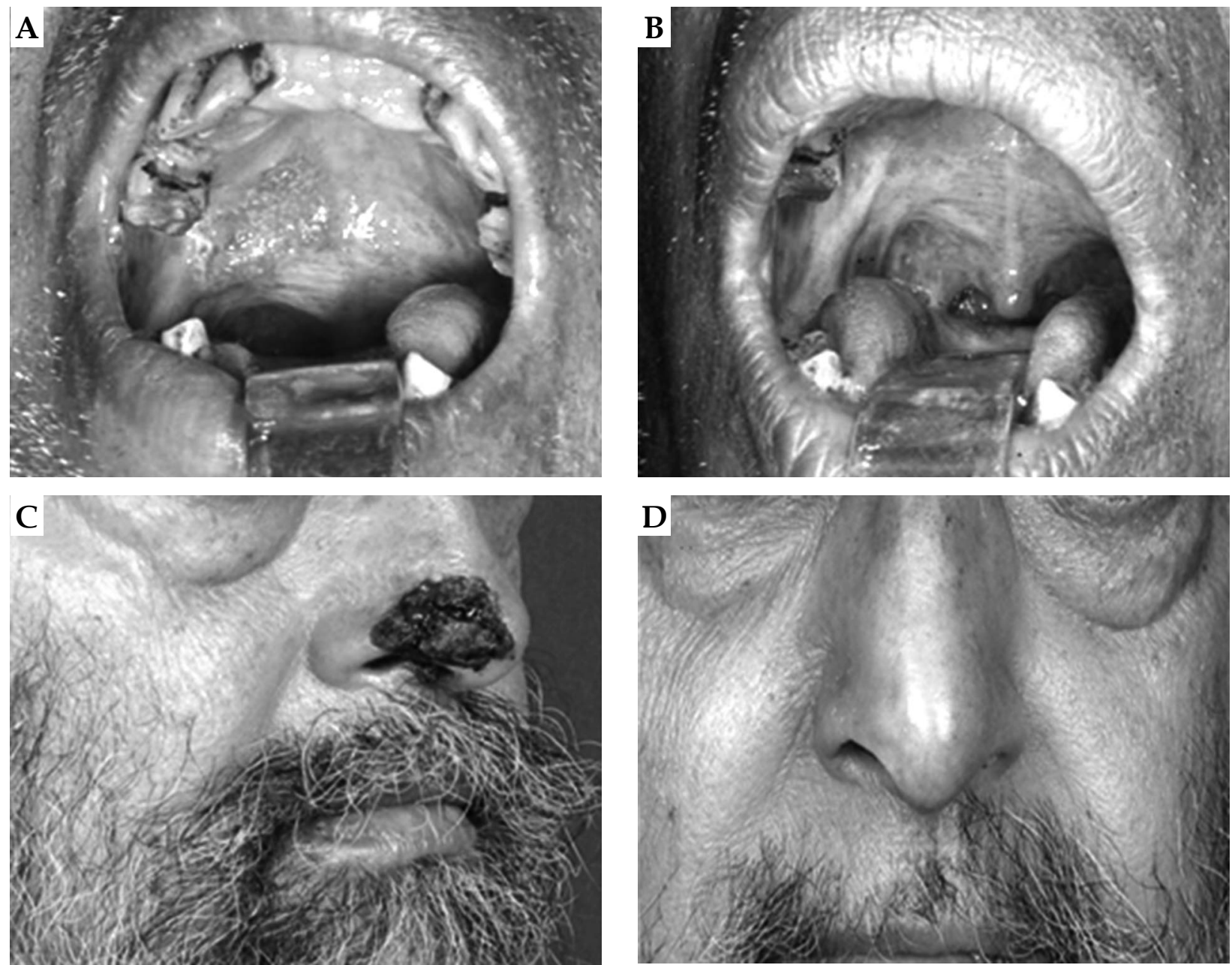

Fig. 4. Clinical outcomes of patients treated with mould brachytherapy. A) Squamous cell carcinoma over right side of hard palate just reaching to the junction of soft palate treated with EBRT and brachytherapy boost. B) Image on follow-up showing locally controlled status with organ preservation. C) Basal cell carcinoma over nose treated with radical surface mould brachytherapy. D) Image on follow-up showing excellent cosmesis

over the nose [9]. Extra caution is therefore required for treating tumours over nose. In such cases, proper fitting of the carrier material needs to be ensured since chances of missing the target volume exist owing to curved surface.

With a median follow-up of 52 months, we have observed LC rate of $76 \%$ for the intraoral tumours. In 15 patients with hard palate primary, the 5-year control rate was $79 \%$ (including 2 treated in recurrent setting). Radical radiotherapy has been reported to result in a 5-year local control of $75 \%$ and $79 \%$ for T1/T2 lesions of hard palate [13,14]. In the present study, of the 7 patients who had T2 lesion of the hard palate, 3 developed nodal failure, which were seen in ipsilateral level IB and II. These patients were treated with SMB alone. In the series reported by Yorozu et al., 5 of 19 SCC patients had developed nodal recurrence subsequently. Similarly, in a series of 17 patients, Mourouzis et al. reported 4 nodal failures in hard palate squamous carcinoma for advanced cases [15]. We suggest elective nodal irradiation for $\mathrm{T} 2$ squamous carcinomas of hard palate, and volumes should encompass ipsilateral level IB and II.

T stage $(p=0.04)$ and dose per fraction $(p=0.003)$ were the only 2 factors, which were statistically significant on univariate analysis of LC. T2 tumours had higher failure rates when compared to $\mathrm{T} 1$. Local control rates have been reported to be poor with increasing tumour size for nasal skin cancers [16]. The LC rate for $>3 \mathrm{~Gy} /$ fraction was $92 \%$, while it was $50 \%$ for 3 Gy per fraction. This could however be due to the fact that $>3$ Gy was considered for skin, while 3 Gy was commonly used for intraoral malignancies. Local control was inferior for recurrent tumours but did not reach significance (Table 3). Similar observation was made by Guix et al. where recurrent tumours had performed inferiorly. In the present study, although significant values were not achieved, all the recurrences were seen in squamous carcinoma. In the series by Guix et al., the only patient to fail for primary treatment setting was of squamous histology.

For preparation of the mould, we had used individualized carrier material. The major benefit of such customized mould is proper fitting of the mould, avoiding underdosage due to improper fitting. Similar technique for treatment of skin tumours were adopted by other authors while fixed applicators were used in some studies $[6,7,8,9]$. For tumours over palate and tonsil, the prepa- 
Table 4. Different studies for high-dose-rate surface mould brachytherapy in head and neck region

\begin{tabular}{|c|c|c|c|c|c|c|c|}
\hline $\begin{array}{l}\text { Author } \\
\text { (year) }\end{array}$ & $\begin{array}{l}\text { Number } \\
\text { of } \\
\text { patients }\end{array}$ & Site & Dose and fraction & Follow-up & Local control & Toxicity & Cosmesis \\
\hline $\begin{array}{l}\text { Svoboda } \\
\text { et al. } \\
\text { (1995) [3] }\end{array}$ & 76 & $\begin{array}{l}\text { All site skin } \\
\text { (9 pinna, } \\
28 \text { head neck) }\end{array}$ & $\begin{array}{l}\text { Radical } 18-22 \text { Gy/1 } \\
\text { fr. to } 50 \text { Gy/15 fr. }\end{array}$ & $\begin{array}{l}9.6 \text { months } \\
\text { (avg) }\end{array}$ & $100 \%$ & $\begin{array}{c}\text { Moist desquamation } \\
\text { in } 22.5 \%\end{array}$ & Excellent \\
\hline $\begin{array}{l}\text { Allan et al. } \\
\text { (1998) [4] }\end{array}$ & 13 & Pinna & $\begin{array}{c}\text { Radical } 44 \text { Gy } \\
\text { @ } 5.5 \text { Gy/fr. }\end{array}$ & $\begin{array}{l}18 \text { months } \\
\text { (minimum) }\end{array}$ & $100 \%$ & $\begin{array}{c}\text { Acute skin toxicity } \\
100 \%\end{array}$ & Excellent \\
\hline $\begin{array}{l}\text { Guix et al. } \\
(2000) \text { [5] }\end{array}$ & 136 & Face & $\begin{array}{l}\text { Radical 60-80 Gy } \\
\text { @ } 1.80 \mathrm{~Gy} / \mathrm{fr} .\end{array}$ & $\begin{array}{l}12 \text { months } \\
\text { (minimum) }\end{array}$ & 5 year $-98 \%$ & $\begin{array}{c}\text { 100\% skin erythema } \\
10 \% \text { skin ulceration } \\
\text { (acute) }\end{array}$ & $\begin{array}{l}92 \% \text { good or } \\
\text { excellent cosmesis }\end{array}$ \\
\hline $\begin{array}{l}\text { Maronas } \\
\text { et al. } \\
(2011)[6]\end{array}$ & 48 & Face & $\begin{array}{c}\text { Radical 48-57 Gy } \\
\text { @ 3-4 Gy/fr. }\end{array}$ & $\begin{array}{l}45 \text { months } \\
\text { (median) }\end{array}$ & $\begin{array}{l}2 \text { year }-91 \% \\
5 \text { year }-89 \%\end{array}$ & $\begin{array}{c}\text { Acute skin toxicity } \\
78 \%\end{array}$ & $\begin{array}{c}\text { Good or very good } \\
\text { late cosmesis }\end{array}$ \\
\hline $\begin{array}{l}\text { Ariji et al. } \\
\text { (1999) [14] }\end{array}$ & 4 & $\begin{array}{l}\text { FOM, BM, } \\
\text { gingival }\end{array}$ & $\begin{array}{l}\text { Boost 25-30 Gy } \\
\text { @ 2.5-3.5 Gy/fr. }\end{array}$ & $\begin{array}{l}14-26 \\
\text { months }\end{array}$ & $100 \%$ & No late toxicity & Not reported \\
\hline $\begin{array}{l}\text { Kudoh } \\
\text { et al. } \\
(2010)[7]\end{array}$ & 2 & $\begin{array}{l}\text { Maxillary } \\
\text { gingiva }\end{array}$ & $\begin{array}{l}\text { Boost (residual) } \\
50 \text { Gy @ } 5 \text { Gy/fr. }\end{array}$ & $\begin{array}{l}2 \text { and } 8 \\
\text { months }\end{array}$ & $100 \%$ & $\begin{array}{c}\text { Grade } 3 \text { mucositis } \\
\text { in } 1\end{array}$ & NA \\
\hline $\begin{array}{l}\text { Matsuzaki } \\
\text { et al. } \\
(2012)[8]\end{array}$ & 6 & BM, lip & $\begin{array}{l}\text { Boost } 24 \text { Gy } \\
\text { @ Gy/fr. }\end{array}$ & $\begin{array}{c}27 \text { months } \\
\text { (median) }\end{array}$ & $\begin{array}{l}1 \text { of } 6 \text { had } \\
\text { local } \\
\text { recurrence }\end{array}$ & $\begin{array}{l}\text { Grade } 2 \text { acute muco- } \\
\text { sitis in all }\end{array}$ & NA \\
\hline $\begin{array}{l}\text { Unetsubo } \\
\text { et al. } \\
\text { (2015) [9] }\end{array}$ & 17 & $\begin{array}{l}\text { BM, gingival, } \\
\text { lip, HP, FOM }\end{array}$ & $\begin{array}{l}\text { Boost } 24 \text { Gy } \\
\text { @ } 6 \text { Gy/fr. }\end{array}$ & $\begin{array}{l}53 \text { months } \\
\text { (median) }\end{array}$ & $\begin{array}{c}3 \text { year and } \\
5 \text { year }-54.1 \%\end{array}$ & $\begin{array}{c}\text { Acute mucositis in } \\
100 \%\end{array}$ & Not reported \\
\hline $\begin{array}{l}\text { Present } \\
\text { study } \\
(2017)\end{array}$ & 35 & $\begin{array}{l}\text { Face, HP, SP, } \\
\text { tonsil }\end{array}$ & $\begin{array}{c}\text { Radical 38.5-52.5 } \\
\text { Gy } \\
\text { Boost 15.5-30 Gy } \\
\text { @ 3-4 Gy/fr. }\end{array}$ & 52 months & $\begin{array}{c}5 \text { year for skin } \\
-92.3 \% \\
\text { and intra-oral } \\
-75.9 \%\end{array}$ & $\begin{array}{c}\text { Grade II or more } \\
\text { acute skin toxicity } \\
\text { in } 17 \% \text { and mucosal } \\
\text { in } 31 \%\end{array}$ & Excellent \\
\hline
\end{tabular}

LC - local control, FOM - floor of mouth, BM - buccal mucosa, HP - hard palate, SP - soft palate, NA - not applicable, fr. - fraction

ration of the mould was done in coordination with department of dentistry. Appropriate fitting was confirmed on planning CT scans. Several authors had reported use of similar technique for intra-oral tumours $[10,12,17]$. In all patients, we have used CT based planning to ensure proper coverage of tumour. Also in few patients, due to improper fitting, the procedure of making the mould was repeated. We suggest careful and meticulous evaluation of the imaging to ensure absence of any air gap between the surface and carrier. The HDR allows the advantage of optimization while planning, and faster treatment delivery. Presently, techniques are under development regarding preparation of computerized 3D mould based on cross sectional imaging. This can be convenient as automated generation and exact reproduction of body contour can possibly lead to better fitting. Clinical outcomes using such techniques are expected to be available in near future.

The compliance was excellent and all patients completed planned treatment. Of significant late toxicities, asymptomatic palatal perforation (approx. $1 \times 1 \mathrm{~cm}$ size) was seen in one patient treated for recurrent setting. Patient was asymptomatic and did not require any intervention for the perforation. The other toxicity seen was exposed bone for primary over hard palate. However, there was disease recurrence at the site of initial disease, so more likely it being due to disease process rather than toxicity. Restricting the depth of prescription to $5-7 \mathrm{~mm}$ can be postulated as plausible reason for reducing late toxicities in our series. The cosmesis was seen to be excellent for all the patients with few developing minimal hypopigmentation.

\section{Conclusions}

Surface mould brachytherapy results in excellent LC rates for skin tumours and should be considered as a standard for management of superficial localized head and neck tumours. This technique results in good LC rate in T1 intraoral tumours when considered as radical treatment, while it may be preferable to consider it as a boost for T2 intraoral tumours. Surface mould brachytherapy results in minimal toxicity with excellent cosmesis and function preservation.

\section{Acknowledgement}

Presented partly at $34^{\text {th }}$ annual meeting of ESTRO in Barcelona in 2015.

\section{Disclosure}

Authors report no conflict of interest. 


\section{References}

1. Kovács G. Modern head and neck brachytherapy: from radium towards intensity modulated interventional brachytherapy. J Contemp Brachytherapy 2015; 6: 404-416.

2. Bansal A, Ghoshal S, Oinam AS et al. High-dose-rate interstitial brachytherapy in early stage oral tongue cancer 15-year experience from a tertiary care institute. J Contemp Brachytherapy 2016; 8: 56-65.

3. Pham A, Arora S, Wernicke G et al. Cesium-131 brachytherapy in high risk and recurrent head and neck cancers: first report of long-term outcomes. J Contemp Brachytherapy 2015; 7: 445-452.

4. Ashby MA, Pacella JA, de Groot $\mathrm{R}$ et al. Use of a radon mold technique for skin cancer: results from the Peter MacCallum Cancer Institute (1975-1984). Br J Radiol 1989; 739: 608-612.

5. Guinot JL, Arribas L, Tortajada MI et al. From low-dose-rate to high-dose-rate brachytherapy in lip carcinoma: Equivalent results but fewer complications. Brachytherapy 2013; 12 528-534.

6. Svoboda VH, Kovarik J, Morris F. High dose-rate microselectron molds in the treatment of skin tumors. Int J Radiat Oncol Biol Phys 1995; 31: 967-972.

7. Allan E, Stanton A, Pye D et al. Fractionated high dose rate brachytherapy olds - a precise treatment for carcinoma of the pinna. Radiother Oncol 1998; 48: 277-281.

8. Guix B, Finestres F, Tello J et al. Treatment of skin carcinomas of the face by high-dose-rate brachytherapy and custom-made surface molds. Int J Radiat Oncol Biol Phys 2000; 47: 95-102.

9. Maroñas M, Guinot JL, Arribas L et al. Treatment of facial cutaneous carcinoma with high-dose rate contact brachytherapy with customized molds. Brachytherapy 2011; 10: 221-227.

10. Kudoh T, Ikushima $H, K u d o h ~ K$ et al. High-dose-rate brachytherapy for patients with maxillary gingival carcinoma using a novel customized intraoral mold technique. Oral Surg Oral Med Oral Pathol Oral Radiol Endod 2010; 109: e102-108.

11. Matsuzaki H, Takemoto M, Hara M et al. Two-piece customized mold technique for high-dose-rate brachytherapy on cancers of the buccal mucosa and lip. Oral Surg Oral Med Oral Pathol Oral Radiol 2012; 113: 118-125.

12. Unetsubo T, Matsuzaki H, Takemoto M et al. High-dose-rate brachytherapy using molds for lip and oral cavity tumors. Radiat Oncol Lond Engl 2015; 10: 81.

13. Chung CK, Johns ME, Cantrell RW et al. Radiotherapy in the management of primary malignancies of the hard palate. Laryngoscope 1980; 90: 576-584.

14. Yorozu A, Sykes AJ, Slevin NJ. Carcinoma of the hard palate treated with radiotherapy: a retrospective review of 31 cases. Oral Oncol 2001; 37: 493-497.

15. Mourouzis C, Pratt C, Brennan PA. Squamous cell carcinoma of the maxillary gingiva, alveolus, and hard palate: is there a need for elective neck dissection? Br J Oral Maxillofac Surg 2010; 48: 345-348.

16. Tsao MN, Tsang RW, Liu FF et al. Radiotherapy management for squamous cell carcinoma of the nasal skin: the Princess Margaret Hospital experience. Int J Radiat Oncol Biol Phys 2002; 52: 973-979.

17. Ariji E, Hayashi N, Kimura Y et al. Customized mold brachytherapy for oral carcinomas through use of high-dose-rate remote afterloading apparatus. Oral Surg Oral Med Oral Pathol Oral Radiol Endod 1999; 87: 508-512. 